\title{
Mast cells infiltrate pancreatic islets in human type 1 diabetes
}

\author{
Luisa Martino $^{1}$ - Matilde Masini ${ }^{1} \cdot$ Marco Bugliani $^{2} \cdot$ Lorella Marselli $^{2}$. \\ Mara Suleiman $^{2}$ - Ugo Boggi ${ }^{1}$. Tatiane C. Nogueira ${ }^{3} \cdot$ Franco Filipponi $^{1}$. \\ Margherita Occhipinti ${ }^{2}$ - Daniela Campani ${ }^{1} \cdot$ Francesco Dotta $^{4}$ - Farooq Syed $^{2}$. \\ Decio L. Eizirik ${ }^{3}$ - Piero Marchetti ${ }^{2}$ Vincenzo De Tata ${ }^{1}$
}

Received: 3 June 2015 / Accepted: 28 July 2015 / Published online: 15 August 2015

(C) Springer-Verlag Berlin Heidelberg 2015

\begin{abstract}
Aims/hypothesis Beta cell destruction in human type 1 diabetes occurs through the interplay of genetic and environmental factors, and is mediated by immune cell infiltration of pancreatic islets. In this study, we explored the role of mast cells as an additional agent in the pathogenesis of type 1 diabetes insulitis.

Methods Pancreatic tissue from donors without diabetes and with type 1 and 2 diabetes was studied using different microscopy techniques to identify islet-infiltrating cells. The direct effects of histamine exposure on isolated human islets and INS-1E cells were assessed using cell-survival studies and molecular mechanisms.

Results A larger number of mast cells were found to infiltrate pancreatic islets in samples from donors with type 1 diabetes, compared with those from donors without diabetes or with type 2 diabetes. Evidence of mast cell degranulation was
\end{abstract}

Piero Marchetti and Vincenzo De Tata contributed equally to this study.

Electronic supplementary material The online version of this article (doi:10.1007/s00125-015-3734-1) contains peer-reviewed but unedited supplementary material, which is available to authorised users.

Vincenzo De Tata

vincenzo.detata@med.unipi.it

1 Department of Translational Research and New Technologies in Medicine and Surgery, University of Pisa, Via Roma 55, 56126 Pisa, Italy

2 Department of Clinical and Experimental Medicine, University of Pisa, Pisa, Italy

3 ULB Center for Diabetes Research, Medical Faculty, Université Libre de Bruxelles (ULB), Brussels, Belgium

4 Department of Medicine, Surgery and Neuroscience, University of Siena, Siena, Italy observed, and the extent of the infiltration correlated with beta cell damage. Histamine, an amine that is found at high levels in mast cells, directly contributed to beta cell death in isolated human islets and INS-1E cells via a caspase-independent pathway.

Conclusions/interpretation These findings suggest that mast cells might be responsible, at least in part, for immunemediated beta cell alterations in human type 1 diabetes. If this is the case, inhibition of mast cell activation and degranulation might act to protect beta cells in individuals with type 1 diabetes.

Keywords Histamine · Human islets · Insulitis · Mast cells · Type 1 diabetes · Type 2 diabetes
Abbreviations
AIF Apoptosis-inducing factor
CCL Chemokine (C-C motif) ligand
CXCL Chemokine (C-X-C motif) ligand

\section{Introduction}

The development and progression of type 1 diabetes results from the autoimmune destruction of pancreatic beta cells. This autoimmune process is triggered by interactions between genetic and environmental factors [1,2], but the exact stimuli and cells participating in this process remain to be determined. This limited understanding of the ultimate triggers and effectors of beta cell death in type 1 diabetes hampers ongoing efforts to prevent or cure the disease.

In most patients, the early stages of type 1 diabetes are associated with immune cell infiltration specifically targeting the islets of Langerhans, which has been termed insulitis 
[1-3]. Well-defined histological criteria to detect insulitis have recently been proposed, i.e. $\geq 15 \mathrm{CD} 45^{+}$(leucocyte common antigen) cells in a minimum of three islets of approximately $150 \mu \mathrm{m}$ diameter [3]. There is also agreement that the majority of infiltrating cells are of lymphocytic nature, with a predominance of $\mathrm{CD}^{+} \mathrm{CD}^{+}$cells in recent-onset type 1 diabetes and an increasing contribution of B lymphocytes $\left(\mathrm{CD} 20^{+}\right)$at later stages $[4,5]$. Innate immunity also plays a role in this process. Thus, significant numbers of islet-infiltrating macrophages have been observed in recent-onset type 1 diabetes $[4,6]$, becoming the most prominent infiltrating cell type in islets devoid of insulin-positive cells [5]. More recently, the presence of leucocytes, including neutrophils, has been observed in the pancreases of individuals with type 1 diabetes, both at onset and at later stages of the disease [7, 8].

In the present study, we show that mast cells are additional agents in the human type 1 diabetes islet-infiltrating cell scenario. These innate immunity cells are normally localised near body surfaces and are consequently considered to be first-line defenders against several environmental insults [9]. Following activation through the classical IgE-dependent or alternative non-IgE-dependent pathways [10], mast cells play a key role in allergic reactions $[8,10,11]$. They possess chemotactic as well as immunomodulatory properties $[9,12]$. Interestingly, a role has been proposed for mast cells in autoimmune disorders such as Crohn's disease, multiple sclerosis and rheumatoid arthritis $[13,14]$, and these cells might also contribute to autoimmune diabetes in experimental animal models such as the BioBreeding rat $[15,16]$. In this study, we show that mast cells infiltrate pancreatic islets during insulitis in human type 1 diabetes and that the extent of the infiltration correlates with beta cell damage. In addition, we show that histamine, an amine that is found at high levels in mast cells, can directly contribute to beta cell death via a caspase-independent apoptotic pathway.

\section{Methods}

Histology Pancreatic samples from seven multiorgan donors without diabetes, six with type 1 diabetes and seven with type 2 diabetes were studied (see Table 1 for details). Approval was obtained from the local ethics committee at the University of Pisa. The type of diabetes was identified based on medical records, anti-GAD autoantibody status and/or the morphological and ultrastructural appearance of pancreatic islets (see electronic supplementary material [ESM] Fig. 1). Pancreatic tissue samples were taken before the islet isolation procedure. Samples were prepared for electron and optical microscopy as previously described $[17,18]$. The specimens acquired for electron microscopy were also used to obtain semithin sections (500 $\mathrm{nm}$ thickness) for light microscopy analysis.
To study mast cells in semithin sections, staining was performed with a $1: 1$ mixture of toluidine blue $(1 \%$ in twicedistilled water) and methylene blue (1\% in twice-distilled water) for $15 \mathrm{~min}$ at $37^{\circ} \mathrm{C}$, with identification of mast cells by light microscopy based on metachromatic staining [19]. For immunohistochemistry studies [17], specimens were fixed in 10\% neutral-buffered formalin (Sigma-Aldrich, St Louis, MO, USA) and embedded in paraffin. Sections $(2 \mu \mathrm{m})$ were then cut, deparaffinised and rehydrated through passages in xylene (Sigma-Aldrich) and graded ethanol (Sigma-Aldrich) solutions. Afterwards, samples were rinsed in PBS and endogenous peroxidases, and inhibited by treatment for $10 \mathrm{~min}$ with $0.5 \%$ hydrogen peroxide. The sections were subsequently rinsed in PBS and treated with normal goat serum blocking solution (Vector Laboratories, Burlingame, CA, USA) at 1:50 dilution for $30 \mathrm{~min}$.

To identify mast cells, we used a monoclonal mouse antibody against tryptase (a mast cell marker [20]) (clone G3; Millipore, Merck, Vimodrone, Italy) at 1:5,000 dilution, with incubation performed overnight at $4^{\circ} \mathrm{C}$. After rinsing with PBS, sections were incubated with the biotinylated secondary antibody (Cell Marque, Rocklin, CA, USA) for $15 \mathrm{~min}$, followed by treatment with the horseradish peroxidase streptavidin label (Cell Marque) for an additional $15 \mathrm{~min}$. Sections were then rinsed in PBS and the diaminobenzidine substrate (Vector Laboratories) was applied for $40 \mathrm{~s}$. After rinsing in double-distilled water, sections were counterstained with Mayer's haematoxylin solution (Sigma-Aldrich), rinsed under running tap water, and then placed in $2 \%$ ammonia solution. Sections were finally dehydrated in ethanol, cleared in xylene and covered with mounting media (Sigma-Aldrich). Images were acquired at $\times 40$ magnification using a Leica DM5500 B microscope (Leica, Wetzlar, Germany).

For the electron microscopy studies (sections $60 \mathrm{~nm}$ thickness), mast cell identification was based on the particular ultrastructural appearance of these cells, including a monolobed nucleus, surface architecture composed of narrow, elongated folds, the presence of typical cytoplasmic granules and the absence of cytoplasmic glycogen aggregates [21, 22]. Lymphocytes and macrophages were identified by electron microscopy, as previously described [23, 24]. Immune system cell counts per $\mathrm{mm}^{2}$ were performed in semithin sections of pancreatic tissue. The same cells were examined by electron microscopy in consecutive ultrathin section to confirm the identification and assess ultrastructural characteristics (Fig. 1).

Counts of inflammatory cells infiltrating the pancreatic islets and of beta cells per islet (together with the calculation of beta cells with signs of apoptosis) were performed with 58 islets ( 20 from donors without diabetes, 18 from donors with type 1 diabetes and 20 from donors with type 2 diabetes) and on tissue sections where recognisable islets (independent of the presence of immune system cells) were identified. The number of pancreatic non-consecutive semithin sections 
Table 1 Relevant characteristics of the organ donors included in the study

\begin{tabular}{|c|c|c|c|c|c|c|c|c|}
\hline Donor & $\begin{array}{l}\text { Age } \\
\text { (years) }\end{array}$ & $\begin{array}{l}\text { Sex } \\
(M / F)\end{array}$ & $\begin{array}{l}\text { BMI } \\
\left(\mathrm{kg} / \mathrm{m}^{2}\right)\end{array}$ & $\begin{array}{l}\text { Cause of } \\
\text { death }\end{array}$ & $\begin{array}{l}\text { ICU stay } \\
\text { (days) }\end{array}$ & $\begin{array}{l}\text { Diabetes } \\
\text { duration } \\
\text { (years) }\end{array}$ & $\begin{array}{l}\text { Anti- } \\
\text { GAD } \\
\text { positivity }\end{array}$ & $\begin{array}{l}\text { Pancreas cold } \\
\text { ischaemia } \\
\text { time }(\mathrm{h})\end{array}$ \\
\hline \multicolumn{9}{|l|}{ No diabetes } \\
\hline 1 & 38 & $\mathrm{~F}$ & 22.5 & CVD & 1 & NA & NA & 16 \\
\hline 2 & 39 & M & 32.6 & CVD & 2 & NA & NA & 16 \\
\hline 3 & 53 & $\mathrm{~F}$ & 25.7 & CVD & 1 & NA & NA & 14 \\
\hline 4 & 22 & M & 19.6 & $\mathrm{~T}$ & 1 & NA & NA & 19 \\
\hline 5 & 62 & M & 34.8 & CVD & 4 & NA & NA & 20 \\
\hline 6 & 74 & M & 23.1 & CVD & 2 & NA & NA & 10 \\
\hline 7 & 61 & $\mathrm{~F}$ & 24.7 & CVD & 2 & NA & NA & 16 \\
\hline Mean \pm SD & $49.9 \pm 16.3$ & - & $26.1 \pm 1.6$ & - & $1.9 \pm 0.7$ & - & - & $15.9 \pm 4.2$ \\
\hline \multicolumn{9}{|l|}{ Type 1 diabetes } \\
\hline 1 & 39 & M & 25.1 & CVD & 2 & 23 & Yes & 12 \\
\hline 2 & 24 & M & 25.7 & $\mathrm{~T}$ & 2 & 2 & Yes & 9 \\
\hline 3 & 73 & $\mathrm{~F}$ & 22.2 & CVD & 1 & 33 & No & 11 \\
\hline 4 & 72 & M & 19.6 & CVD & 2 & 51 & No & 20 \\
\hline 5 & 61 & $\mathrm{~F}$ & 25.7 & CVD & 1 & NAv & Yes & 13 \\
\hline 6 & 73 & M & 26.1 & CVD & 1 & 10 & Yes & 16 \\
\hline Mean \pm SD & $57.0 \pm 20.8$ & - & $24.1 \pm 2.6$ & - & $1.5 \pm 0.5$ & $23.8 \pm 19.3$ & - & $13.5 \pm 3.9$ \\
\hline \multicolumn{9}{|l|}{ Type 2 diabetes } \\
\hline 1 & 68 & M & 27.8 & CVD & 9 & 6 & No & 11 \\
\hline 2 & 79 & M & 24.7 & CVD & 1 & 9 & No & 12 \\
\hline 3 & 72 & M & 32.4 & CVD & 1 & 11 & No & 15 \\
\hline 4 & 76 & M & 26.0 & $\mathrm{~T}$ & 2 & 12 & NAv & 16 \\
\hline 5 & 53 & $\mathrm{~F}$ & 33.1 & CVD & 2 & NAv & No & 12 \\
\hline 6 & 78 & M & 25.9 & $\mathrm{~T}$ & 2 & 12 & NAv & 13 \\
\hline 7 & 76 & M & 24.5 & CVD & 1 & 7 & No & 13 \\
\hline Mean \pm SD & $71.0 \pm 5.7$ & - & $27.8 \pm 2.3$ & - & $2.6 \pm 5.7$ & $10 \pm 2.5$ & - & $13.1 \pm 1.4$ \\
\hline
\end{tabular}

CVD, cardiovascular disease; F, female; ICU, intensive care unit; M, male; NA, not applicable; NAv, not available; T, trauma

(one every ten sections) examined to reach these numbers of islets was 145 in control cases (with $3 \pm 1$ blocks and $21 \pm 8$ sections per patient), 568 in samples from donors with type 1 diabetes ( $10 \pm 3$ blocks and $95 \pm 26$ sections per patient) and 240 in samples from donors with type 2 diabetes $(5 \pm 1$ blocks and $34 \pm 15$ sections per patient). All counts were independently performed by two investigators unaware of sample identity (samples were identified only by randomly assigned numbers).

Quantification of beta cells (including those with apoptotic features) was performed as previously detailed [18, 25-27]. Beta cells were identified based on the presence of typical insulin granules, while apoptotic beta cells were identified based on the appearance of marked chromatin condensation and/or blebs (ESM Fig. 2), as previously reported by us and others $[18,25,28]$. Islets isolated from independent nondiabetic donors were also studied histologically after exposure to histamine (see below). In such cases, in addition to electron microscopy experiments, immunofluorescence analysis was performed to identify insulin-containing cells and TUNELpositive cells, similar to previously published procedures $[17,29]$. To do this, pancreas sections were deparaffinised, rehydrated through passages in xylene and graded ethanol solutions, and rinsed in PBS. Antigen retrieval was then performed using citrate buffer ( $\mathrm{pH} 6)$ in a microwave at $350 \mathrm{~W}$ for $5 \mathrm{~min}$. Insulin immunostaining was performed using a primary, polyclonal guinea pig anti-insulin antibody (Abcam, Cambridge, UK) at 1:100 dilution, applied for $1 \mathrm{~h}$ at room temperature, followed by treatment with the secondary antibody (Alexa Fluor 594-conjugated donkey anti-guinea pig IgG; Jackson ImmunoResearch, Pero, Italy) at 1:200 dilution for $1 \mathrm{~h}$ at room temperature. The presence of apoptotic cells was confirmed using the In Situ Cell Death Detection Kit (Roche, Mannheim, Germany). Sections were incubated with a reaction solution containing the terminal deoxynucleotidyl transferase enzyme and fluorescein-dUTP labelled 

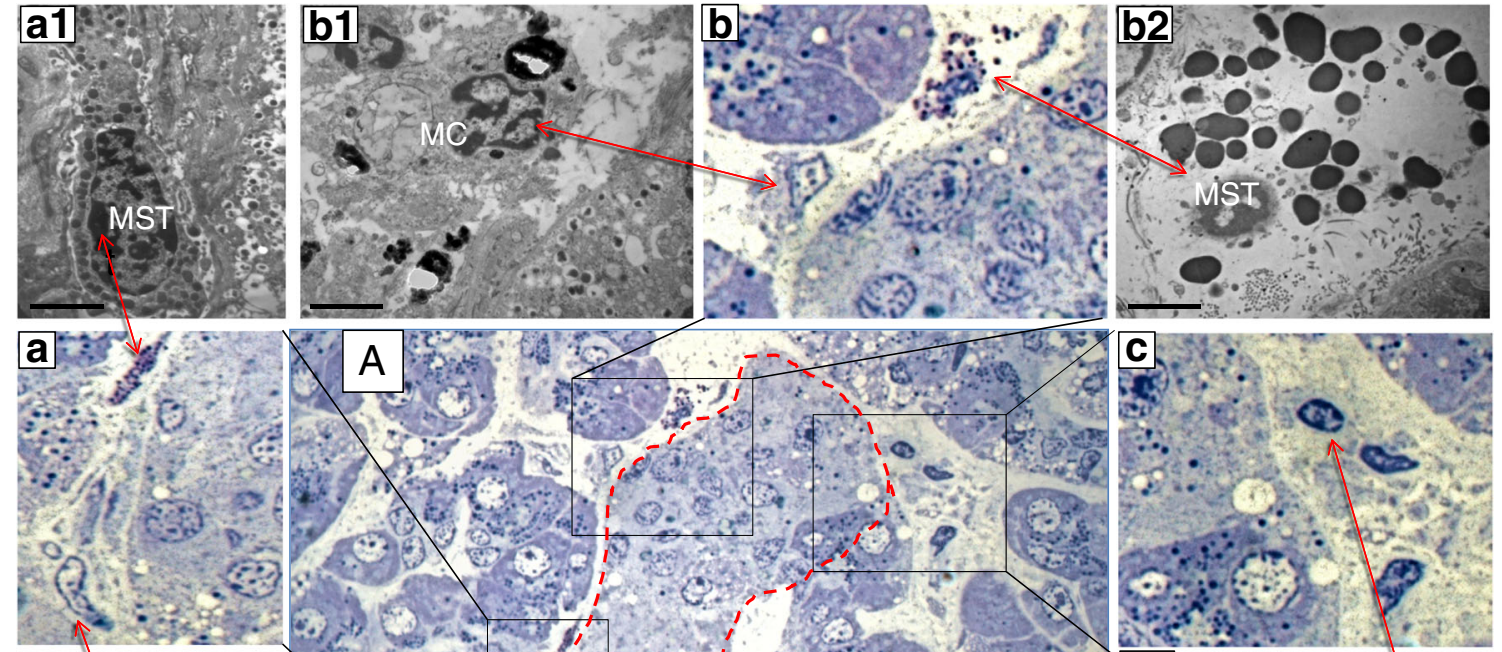
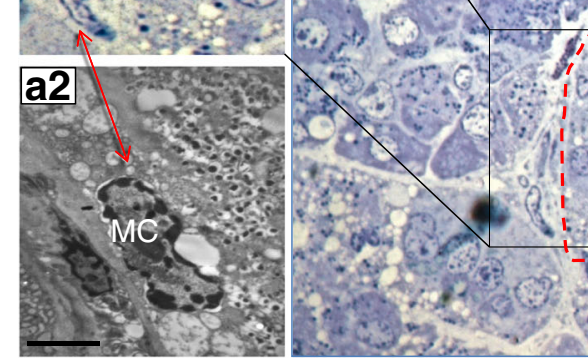

Fig. 1 Consecutive semithin and ultrathin sections of a pancreas sample from a donor with type 1 diabetes (type 1 diabetes, donor 1 in Table 1) showing (A) a pancreatic islet (dashed line) surrounded by infiltrate containing different inflammatory cells $(\times 1,000)$. The comparison between consecutive semithin and ultrathin sections illustrates how the identification of the different types of inflammatory cells in the semithin section was confirmed by electron microscopy. $(\mathbf{a}-\mathbf{c}) \times 1,000$ magnification (semithin sections) of the corresponding images in (A); (a1,a2): electron microscopy images of a mast cell (MST) and macrophage (MC) identified in (a) $(\times 10,000)$; (b1,b2) electron microscopy images of an $\mathrm{MC}$ and degranulating MST identified in (b) $(\times 10,000)$; (c1) electron microscopy of a lymphocyte (L) identified in $(\mathbf{c})(\times 10,000)$. Scale bars correspond to $10 \mu \mathrm{m}$ in $\mathbf{A}$, and to $1 \mu \mathrm{m}$ in $\mathbf{a 1}, \mathbf{a} 2, \mathbf{b} 1, \mathbf{b} 2$ and $\mathbf{c 1}$ nucleotides (TUNEL reaction mixture) (In Situ Cell Death Detection Kit; Roche) for $1 \mathrm{~h}$ at $37 \mathrm{C}$. Analysis was performed at $\times 400$ magnification using a Leica DM5500B microscope. All counts were independently performed by two investigators unaware of sample identity (samples were identified by randomly assigned numbers).

Islet isolation and incubation Isolated islets were prepared from the pancreases of 18 independent non-diabetic multiorgan donors (age $69 \pm 15.5$ years; ten male; BMI 26.2 $\pm 3.1 \mathrm{~kg} / \mathrm{m}^{2}$; cause of death: 14 cardiovascular events and four traumas; duration of intensive care unit stay $3 \pm 2$ days; pancreas cold ischaemia time $18.3 \pm 6.2 \mathrm{~h}$ ) by collagenase digestion followed by density gradient purification, as previously reported $[18,26]$. After isolation, the islets were maintained for 2-3 days in M199 medium, containing $5.5 \mathrm{mmol} / \mathrm{l} \mathrm{glu-}$ cose, supplemented with $10 \%$ serum and antibiotics. Batches of approximately 1,000 islets were then cultured for $72 \mathrm{~h}$ in M199 medium supplemented with 10\% (vol./vol.) serum and $100 \mathrm{U} / \mathrm{ml}$ penicillin, $100 \mu \mathrm{g} / \mathrm{ml}$ streptomycin, $50 \mu \mathrm{g} / \mathrm{ml}$ gentamicin and $750 \mathrm{ng} / \mathrm{ml}$ amphotericin B, and either with or without the addition of $100 \mu \mathrm{mol} / 1$ histamine dihydrochloride (all Sigma-Aldrich). In some experiments, the effect of caspase inhibition by $20 \mu \mathrm{mol} / \mathrm{l}$ Z-VAD-FMK (Promega, Madison, WI, USA) was also tested.

Western blot experiments Isolated human islets were lysed in buffer containing $40 \mathrm{mmol} / \mathrm{l}$ Tris, $4 \%$ CHAPS, $7 \mathrm{~mol} / \mathrm{l}$ urea, $2 \mathrm{~mol} / \mathrm{l}$ thiourea and $1 \% \mathrm{DTT}$, and supplemented with a protease inhibitor cocktail (Roche). The lysates were centrifuged to remove cellular debris and the protein amount was evaluated using the Bradford method. A western blot assay of caspase 9 and 3 activation in human islets incubated for $24 \mathrm{~h}$ with histamine (see above) was performed as previously described [30]. Briefly, equal amounts of total protein were heated at $100^{\circ} \mathrm{C}$ for $5 \mathrm{~min}$, resolved by SDS-PAGE and electroblotted onto nitrocellulose membranes. Immunodetection was performed after overnight incubation with antibodies for cleaved caspase 9 and 3 (Cell Signaling, Danvers, MA, USA), and $\alpha$-tubulin (Cell Signaling) was used as the loading control.

Gene expression studies Gene expression was determined as previously described $[18,30,31]$. Briefly, total RNA was extracted using the PureLink RNA Mini Kit (Life Technologies, Carlsbad, CA, USA) and quantified by absorbance at A260/A280 nm (ratio > 1.9) in a NanoDrop 2000C 
spectrophotometer (Euroclone Spa, Pero, Italy). RNA integrity was assessed using an Agilent 2100 Bioanalyzer (Agilent Technologies, Cernusco sul Naviglio, Italy). For quantitative PCR experiments, total RNA was reversetranscripted from $1 \mu \mathrm{g}$ using a SuperScript VILO cDNA Synthesis Kit (Life Technologies). The oligonucleotides of interest were obtained from assay-on-demand gene expression products (Life Technologies). mRNA levels were quantified and normalised for $\beta$-actin using a ViiA 7 analyser (Life Technologies).

Mitochondrial studies The activity of mitochondrial complex I was assayed in control and histamine-treated (72 h) INS-1E cells (kindly provided by C. Wollheim; University of Geneva, Geneva, Switzerland) using a commercially available kit (Mitochondrial Complex I Activity Assay Kit; Millipore, Darmstadt, Germany) and following the manufacturer's instructions. INS-1E cells were cultured in a humidified atmosphere containing $5 \% \mathrm{CO}_{2}$ in complete medium composed of RPMI 1640 supplemented with $10 \%$ heat-inactivated FCS, $1 \mathrm{mmol} / 1$ sodium pyruvate, $50 \mu \mathrm{mol} / 1$ 2-mercaptoethanol, $2 \mathrm{mmol} / \mathrm{l}$ glutamine, $10 \mathrm{mmol} / \mathrm{l} \mathrm{HEPES}, 100 \mathrm{U} / \mathrm{ml}$ penicillin and $100 \mu \mathrm{g} / \mathrm{ml}$ streptomycin [27]. The mitochondrial membrane potential in control and histamine-treated INS-1 cells was measured cytofluorimetrically, as previously described [32], with a FACScan equipped with CellQuest software (BD Biosciences, Franklin Lakes, NJ, USA).
Statistical analysis Results are given as means $\pm \mathrm{SD}$, and differences between groups were assessed using the two-tailed Student's $t$ test or ANOVA with Bonferroni correction, as appropriate. Unilinear regression analysis was also performed to evaluate correlations between selected variables. A $p$ value of $<0.05$ was considered statistically significant.

\section{Results}

As illustrated in Fig. 1 (see also Methods), consecutive semithin and ultrathin sections of pancreases from donors with type 1 diabetes showed infiltrates containing different inflammatory cells, including lymphocytes, macrophages and mast cells. Representative images of mast cells identified by different microscopy techniques are shown in Fig. 2, demonstrating the presence of this cell type in non-endocrine tissue as well as in both the peri- and intra-insular regions. Quantification of mast cells in non-endocrine tissue was performed using semithin sections, and the count of these cells at the periphery of and inside islets was also performed using electron microscopy analysis (Fig. 2a-c). There were $8.2 \pm 2.5$ and $18.2 \pm 4.3$ mast cells $/ \mathrm{mm}^{2}$ in pancreatic samples from donors without diabetes and with type 1 diabetes, respectively $(p<0.05)$, whereas the number of mast cells in specimens from donors with type 2 diabetes $\left(6.6 \pm 1.3\right.$ per $\left.\mathrm{mm}^{2}\right)$ was similar to that of controls.
Fig. 2 Micrographs of a pancreas sample from a donor with type 1 diabetes (type 1 diabetes, donor 2 in Table 1) after (a, d) immunocytochemistry, (b, e) semithin section analysis and (c, f) electron microscopy. (a-c) Mast cells (arrows in $\mathbf{a}$ and $\mathbf{b}$, and MST in $\mathbf{c}$ ) in non-endocrine tissue. (d-f) Mast cells (arrows in $\mathbf{d}$ and $\mathbf{e}$, and MST in $\mathbf{f}$ ) in the periinsular region and within islets. Dashed red lines indicate pancreatic islets. Scale bars correspond to $25 \mu \mathrm{m}$ in a and d, $10 \mu \mathrm{m}$ in $\mathbf{b}$ and $\mathbf{e}$, and $1 \mu \mathrm{m}$ in $\mathbf{c}$ and $\mathbf{f}$

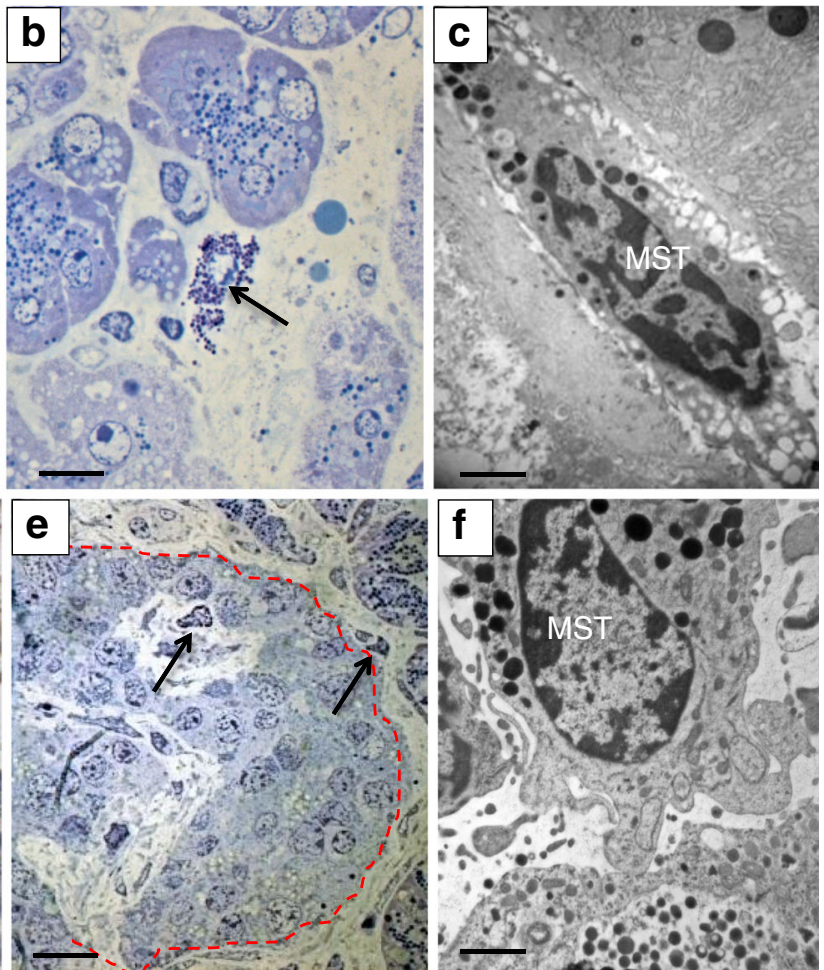
In agreement with previous reports [5, 33, 34] we observed that lymphocyte and macrophage cell numbers were significantly increased in samples from donors with type 1 diabetes, while there was an increase in macrophages but not in lymphocytes in type 2 diabetes pancreatic sections. Thus, lymphocyte numbers (cells $/ \mathrm{mm}^{2}$ pancreatic tissue) were $2.8 \pm 1.3$ in samples from non-diabetic donors, $36.4 \pm 7.3$ in samples from donors with type 1 diabetes ( $p<0.05$ vs no diabetes and type 2 diabetes) and $2.9 \pm 1.0$ in samples from donors with type 2 diabetes. Macrophage numbers (cell $/ \mathrm{mm}^{2}$ pancreatic tissue) were $5.2 \pm 1.8$ in non-diabetic, $13.2 \pm 1.2$ in type 1 diabetic $(p<0.05$ vs non-diabetic) and $18.1 \pm 3.0$ in type 2 diabetic ( $p<0.05$ vs non-diabetic) samples. Details on the number of different pancreatic tissue infiltrating cells per patient are shown in ESM Fig. 3.

The number of beta cells counted (cells $/ \mathrm{mm}^{2}$ pancreatic tissue) was 643, 499 and 598 in samples from control and type 1 and 2 diabetic donors, respectively. The proportion of islet beta cells with signs of apoptosis was $0.5 \pm 0.4 \%$ in samples from control donors, $6.5 \pm 3.8 \%$ in samples from donors with type 1 diabetes and $4.9 \pm 1.5 \%$ in samples from donors with type 2 diabetes (both $p<0.05$ vs controls). The proportion of islets with at least one mast cell was $27 \%, 94 \%$ and $33 \%$, respectively ( $p<0.05$ for type 1 diabetes vs no diabetes; nonsignificant for type 2 diabetes vs no diabetes). Mast cell numbers per islet per patient were $0.6 \pm 0.3$ in control samples, $2.0 \pm 0.7$ in type 1 diabetes samples $(p<0.05$ vs control and type 2 diabetes) and $0.7 \pm 0.2$ in type 2 diabetes samples (ESM Fig. 4). In addition, in control and type 2 diabetes samples, practically all the mast cells were located at the periphery of the islets, whereas in the type 1 diabetes samples, about $40 \%$ of the mast cells $(0.8 \pm 0.3$ per islet per patient) were located within the islets (Fig. 2d-f). Of interest, several mast cells in type 1 diabetes samples appeared to be at least partially degranulated (Fig. 3).
With respect to the other mononuclear cells (ESM Fig. 4), the number of macrophages located at the periphery and within the islets was $0.9 \pm 0.2$ per islet per patient in control samples, $1.9 \pm 0.4$ per islet per patient in type 1 diabetes samples $(p<0.05$ vs control) and $4.3 \pm 0.7$ per islet per patient in type 2 diabetes samples $(p<0.05$ vs control), with three- to fourfold higher values (both $p<0.05$ vs non-diabetic) for intra-islet macrophages in type $1(0.3 \pm 0.1)$ and type $2(0.4 \pm 0.3)$ diabetes compared with non-diabetic control samples $(0.1 \pm 0.06)$. The corresponding figures for lymphocytes were $0.2 \pm 0.1$ per islet per patient in non-diabetic samples (all at the periphery), $0.9 \pm 0.3$ per islet per patient in type 1 diabetes samples (of which $0.8 \pm 0.3$ per islet per patient were within the islet, $p<0.05$ vs non-diabetic) and $0.7 \pm 0.2$ in type 2 diabetes samples (of which only $0.1 \pm 0.1$ per islet per patient were within the islet, not significantly different vs no diabetes and $p<0.05$ vs type 1 diabetes) (ESM Fig. 4).

In type 1 diabetes samples, the number of mast cells per $\mathrm{mm}^{2}$ of pancreatic tissue showed a trend towards an inverse correlation with the duration of diabetes $(r=0.73, p=0.06)$, suggesting attenuation of infiltration over time; however, the number of islet-infiltrating mast cells was not affected by disease duration $(r=0.10)$. Interestingly, the number of beta cells with signs of apoptosis was positively correlated with the number of mast cells in and around islets (per islet: $r=0.62$, $p<0.01$; per patient: $r=0.75, p=0.05$ ).

Because histamine is one of the most abundant compounds stored by mast cells $[9,14]$, we next tested if direct exposure of isolated non-diabetic human islets to this amine affects beta cell survival. After $72 \mathrm{~h}$ incubation, the proportion of beta cells with signs of apoptosis was $1.0 \pm 0.6 \%$ in control islets (out of 257 beta cells counted by electron microscopy) and $6.1 \pm 2.0 \%$ (out of 306 beta cells counted) in islets incubated with $100 \mu \mathrm{mol} / 1$ histamine $(p<0.01)$. Accordingly, the proportion of insulin-positive cells showing TUNEL-positive nuclei

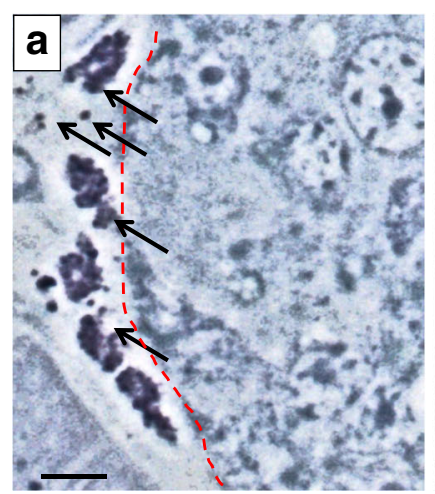

Fig. 3 Micrographs of a pancreas sample from a donor with type 1 diabetes (type 1 diabetes, case 4 in Table 1) to evaluate morphological evidence of mast cell activation. (a) Semithin section: a degranulated mast cell is shown in the peri-insular region (arrows); the dashed red line indicates the pancreatic islet. (b, c) Electron microscopy images showing
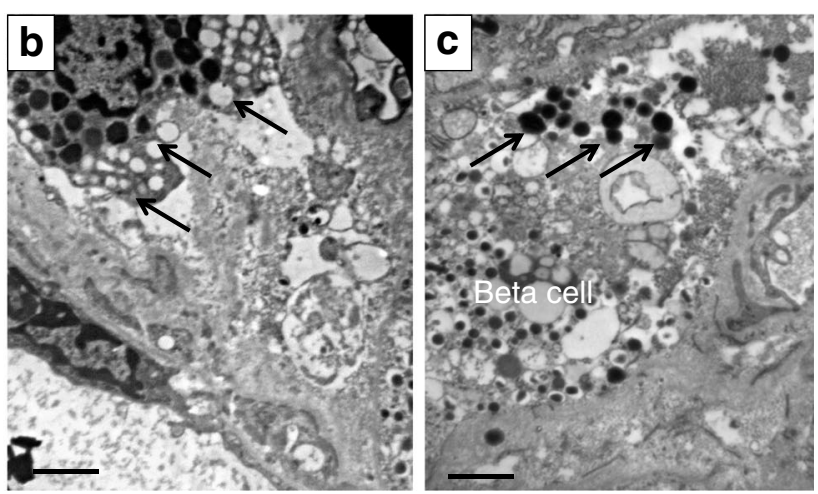

(b) mast cells with signs of degranulation (arrows indicate mast cell granules and hollow granules in the cytoplasm) and (c) free mast cell granules (arrows) in close proximity to a beta cell $(\times 10,000$ magnification). Scale bars correspond to $10 \mu \mathrm{m}$ in panel a, and to $1 \mu \mathrm{m}$ in panels $\mathbf{b}$ and $\mathbf{c}$ 
(ESM Fig. 5) was $2.8 \pm 1.6 \%$ in histamine-treated human islets (301 insulin-positive cells counted), which was significantly higher than in islets that were not exposed to the amine $(0.6 \pm 0.5 \%, 393$ insulin-positive cells counted).

In order to investigate the mechanisms involved in histamine-related beta cell apoptosis, we tested the activation of caspases 9 and 3 by western blotting. As shown in Fig. 4a, no difference in cleaved caspases was observed in islets that were either exposed or not exposed to histamine. In line with these observations, the presence of a caspase inhibitor did not significantly reduce the extent of beta cell apoptosis following histamine exposure, as assessed with an electron microscope (Fig. 4b). Of note, an intrinsic form of caspase-independent apoptosis has been described [28]. In this case, molecules such as apoptosis-inducing factor (AIF) are released from the mitochondria, translocate to the nucleus and mediate DNA fragmentation [28]. Intriguingly, we observed significantly increased expression of AIF (also known as AIFMI) in human islets exposed to histamine (Fig. 4c). The impact of histamine on mitochondria was confirmed by experiments performed in insulin-producing INS-1E cells. Thus, we noticed that a $72 \mathrm{~h}$ incubation with $100 \mu \mathrm{mol} / 1$ histamine was associated with inhibition of mitochondrial complex I enzyme activity $(p<0.05)$ (Fig. 4d) and depolarisation of the mitochondrial membrane potential, as assayed by cytofluorometry $(p<0.01)$ (Fig. 4e).

\section{Discussion}

To the best of our knowledge, mast cell infiltration of human pancreatic islets has not previously been described for individuals with type 1 diabetes. In this study, we found that the number of these innate immune system cells was increased in islets from donors with type 1 diabetes and correlated with the proportion of beta cells with signs of apoptosis. These findings cannot be explained by differences in cause of death, duration of intensive care unit stay or pancreas cold ischaemia time, which can all affect the degree and composition of pancreas infiltration [35], since these variables were similar between control donors without diabetes and donors with type 1 diabetes (Table 1). In addition, mast cell infiltration was not seen in islets from donors with type 2 diabetes, suggesting that this feature is peculiar to type 1 diabetes. Finally, we have demonstrated that histamine, an amine that is found at high levels in mast cells, can induce beta cell apoptosis, possibly by activating an intrinsic, caspase-independent apoptotic machinery. This pathway is characterised by mitochondrial dysfunction and release of mitochondrial proteins such as AIF, which can directly fragment DNA without the need for caspase activation [28]. In line with this possibility, we observed that histamine upregulates $A I F$ expression and that the use of a caspase inhibitor does not prevent beta cell apoptosis.


Fig. 4 Effects of histamine exposure $(100 \mu \mathrm{mol} / 1$ for $72 \mathrm{~h})$ on isolated human islets (a-c) and INS-1E cells (d, e). (a) Levels of cleaved (active) caspases 9 and 3 in human islets either not exposed (control) or exposed to histamine. (b) Proportion of beta cells with signs of apoptosis in control human islets and human islets exposed to caspase inhibitor alone, histamine alone or caspase inhibitor plus histamine. ${ }^{*} p<0.05$ (Bonferroni corrected) vs control islets and islets exposed to caspase inhibitor alone.

(c) Gene expression by quantitative PCR of $A I F$ (expression corrected for $\beta$-actin) in control islets and islets exposed to histamine. ${ }^{*} p<0.05$ by Student's $t$ test. (d) Mitochondrial complex 1 enzyme activity in INS$1 \mathrm{E}$ cells exposed or not to histamine. ${ }^{*} p<0.05$ by Student's $t$ test. (e) Cytofluorimetric analysis of the mitochondrial membrane potential in INS-1E cells exposed or not to histamine. Purple line, control; green line, histamine 
Overall, the present results are coherent with the observation of human islet infiltration by other cells of the innate immune system $[7,8]$ and with the concept that mast cells might be involved in autoimmune processes, including experimental diabetes $[13,15,16]$. A recent study, however, questioned the role of mast cells in the pathogenesis of diabetes in the NOD mouse [36], suggesting differences between species regarding the role of different cellular effectors of innate immunity in causing beta cell damage. Of interest, in our study, mast cells were also present in islets obtained from individuals with longterm diabetes, suggesting that components of the innate immune response might continue to contribute to beta cell dysfunction and death even after putative full activation of the adaptive immune response. Similar observations have been reported for leucocyte infiltration [7].

At the moment, it is not clear why mast cells move into the islets in individuals with type 1 diabetes. These cells are actively involved in the recognition of viruses and viral products [9]. Since viral infections have been implicated in the pathogenesis of beta cell damage in type 1 diabetes [37], it is conceivable that the presence of a viral infection and local inflammation in islets attract these cells. In line with this, mast cells are attracted to tissues expressing chemokine (C-C motif) ligand (CCL)2, CCL3, CCL5, chemokine (C-X-C motif) ligand (CXCL) 2 and CXCL4, among others [38], and human islets exposed to viral infection [39] or proinflammatory cytokines $[40,41]$ express high levels of these chemokines.

Of note, besides the above-described invasion of pancreatic islets, we also observed an increased number of mast cells and other immune cells in the exocrine pancreas. It has been previously reported that pancreatic weight and volume are significantly reduced in individuals with type 1 diabetes [42], and recent findings indicate that leucocytes and CD8 and CD4 T cells infiltrate the exocrine pancreas in these individuals $[7,43]$. Taken together with our present findings, these studies support the concept that inflammation of the pancreas as a whole might contribute to the pathogenesis of type 1 diabetes [44].

Intriguingly, electron microscopy examination showed that at least some islet-infiltrating mast cells are partially degranulated, indicating functional activation. Mast cells can be activated through the classical IgE-dependent or the alternative non-IgE-dependent pathways via toll-like receptors [10]. In preliminary immunohistochemical experiments, we have observed that the mast cells in the pancreatic tissue of type 1 diabetes patients are anti-IgE negative (L. Martino and M. Masini, unpublished observations), favouring the view of an activation triggered via toll-like receptors [9]. Once activated, mast cells can recruit other inflammatory and immune cells [45] and/or directly damage beta cells by releasing histamine (as suggested by our results), with both effects potentially contributing to beta cell dysfunction and death. In line with this hypothesis, histamine receptors are produced in mouse and human pancreatic beta cells [46], and both pizotifen, an inhibitor of histamine action, and disodium cromoglycate, an inhibitor of mast cell degranulation, suppress diabetes development in C57B1/6J mice treated with multiple low doses of streptozotocin [47].

In conclusion, the present observations suggest that mast cells make a putative contribution to immune-mediated beta cell dysfunction and death in individuals with type 1 diabetes. If these observations are confirmed by additional studies with larger numbers of samples, it will suggest that inhibitors of histamine action or mast cell degranulation might be considered as adjuvant therapies to protect beta cells in human type 1 diabetes.

Funding This work was supported by grants from the EU (projects Naimit and BetaBat, in the Framework Programme 7 of the European Community); the Italian Ministry of University and Research (PRIN 2010-2011); the Fonds National de la Recherche Scientifique (FNRS), Belgium; and the Communauté Française de Belgique-Actions de Recherche Concertée (ARC).

Duality of interest The authors declare that there is no duality of interest associated with this manuscript.

Author contributions LMart, MM, DLE, PM and VDT conceived the study, designed the experiments, analysed and interpreted data, and wrote the manuscript. UB, FF, MB, LMars, MO, MS, FS, DC, FD and TCN contributed to the acquisition and interpretation of data. All the authors revised the manuscript critically for important intellectual content and gave final approval of the version to be published. VDT is the guarantor of this work and, as such, had full access to all of the data in the study and takes responsibility for the integrity of the data and the accuracy of the data analysis.

\section{References}

1. Bluestone JA, Herold K, Eisenbarth G (2010) Genetics, pathogenesis and clinical interventions in type 1 diabetes. Nature 464:12931300

2. Eizirik DL, Colli ML, Ortis F (2009) The role of inflammation in insulitis and beta-cell loss in type 1 diabetes. Nat Rev Endocrinol 5:219-226

3. Campbell-Thompson ML, Atkinson MA, Butler AE et al (2013) The diagnosis of insulitis in human type 1 diabetes. Diabetologia 56:2541-2543

4. Hänninen A, Jalkanen S, Salmi M, Toikkanen S, Nikolakaros G, Simell O (1992) Macrophages, T cell receptor usage, and endothelial cell activation in the pancreas at the onset of insulin-dependent diabetes mellitus. J Clin Invest 90:1901-1910

5. Willcox A, Richardson SJ, Bone AJ, Foulis AK, Morgan NG (2009) Analysis of islet inflammation in human type 1 diabetes. Clin Exp Immunol 155:173-181

6. Lernmark A, Klöppel G, Stenger D et al (1995) Heterogeneity of islet pathology in two infants with recent onset diabetes mellitus. Virchows Arch 425:631-640

7. Reddy S, Zeng N, Al-Diery H et al (2015) Analysis of peri-islet CD45-positive leucocytic infiltrates in long-standing type 1 diabetic patients. Diabetologia 58:1024-1035 
8. Valle A, Giamporcaro GM, Scavini M et al (2013) Reduction of circulating neutrophils precedes and accompanies type 1 diabetes. Diabetes 62:2072-2077

9. Weller CL, Collington SJ, Williams T, Lamb JR (2011) Mast cells in health and disease. Clin Sci (Lond) 120:473-484

10. Rivera J, Gilfillan AM (2006) Molecular regulation of mast cell activation. J Allergy Clin Immunol 117:1214-1225

11. Castleman WL, Sorkness RL, Lemanske RF Jr, McAllister PK (1990) Viral bronchiolitis during early life induces increased numbers of bronchiolar mast cells and airway hyperresponsiveness. Am J Pathol 137:821-831

12. Galli SJ, Nakae S, Tsai M (2005) Mast cells in the development of adaptive immune responses. Nat Immunol 6:135-142

13. Walker ME, Hatfield JK, Brown MA (2012) New insights into the role of mast cells in autoimmunity: evidence for a common mechanism of action? Biochim Biophys Acta 1822:57-65

14. da Silva EZ, Jamur MC, Oliver C (2014) Mast cell function: a new vision of an old cell. J Histochem Cytochem 62:698-738

15. Pino SC, Kruger AJ, Bortell R (2010) The role of innate immune pathways in type 1 diabetes. Curr Opin Endocrinol Diabetes Obes 17:126-130

16. Geoffrey R, Jia S, Kwitek AE et al (2006) Evidence of a functional role for mast cells in the development of type 1 diabetes mellitus in the BioBreeding rat. J Immunol 177:7275-7286

17. Marselli L, Bugliani M, Suleiman M et al (2013) Beta-cell inflammation in human type 2 diabetes and the role of autophagy. Diabetes Obes Metab 15(Suppl 3):130-136

18. Masini M, Bugliani M, Lupi R et al (2009) Autophagy in human type 2 diabetes pancreatic beta cells. Diabetologia 52:1083-1086

19. Abdou AG, Maraee AH, Antar AG, Fareed S (2014) Role of mast cells in skin tag development: an immunohistochemical study. Anal Quant Cytopathol Histpathol 36:222-230

20. Vitte $J$ (2015) Human mast cell tryptase in biology and medicine. Mol Immunol 63:18-24

21. Dvorak AM (2005) Ultrastructural studies of human basophils and mast cells. J Histochem Cytochem 53:1043-1070

22. Wernersson S, Pejler G (2014) Mast cell secretory granules: armed for battle. Nat Rev Immunol 14:478-494

23. Sturrock RR (1979) A semithin light microscopic, transmission electron microscopic and scanning electron microscopic study of macrophages in the lateral ventricle of mice from embryonic to adult life. J Anat 129:31-44

24. Seemayer TA, Tannenbaum GS, Goldman HY, Colle E (1982) Dynamic time course studies of the spontaneously diabetic BB Wistar rat III. Light-microscopic and ultrastructural observation of pancreatic islets of Langerhans. Am J Pathol 106:237-249

25. Kroemer G, Galluzzi L, Vandenabeele P et al (2009) Classification of cell death: recommendations of the Nomenclature Committee on Cell Death 2009. Cell Death Differ 16:3-11

26. Marchetti P, Bugliani M, Lupi R et al (2007) The endoplasmic reticulum in pancreatic beta cells of type 2 diabetes patients. Diabetologia 50:2486-2494

27. Martino L, Masini M, Novelli M et al (2012) Palmitate activates autophagy in INS-1E $\beta$-cells and in isolated rat and human pancreatic islets. PLoS One 7(5):e36188

28. Galluzzi L, Vitale I, Abrams JM et al (2012) Molecular definitions of cell death subroutines: recommendations of the Nomenclature Committee on Cell Death 2012. Cell Death Differ 19:107-120

29. Meier JJ, Bhushan A, Butler AE, Rizza RA, Butler PC (2005) Sustained beta cell apoptosis in patients with long-standing type 1 diabetes: indirect evidence for islet regeneration? Diabetologia 48: 2221-2228
30. Nogueira TC, Paula FM, Villate O et al (2013) GLIS3, a susceptibility gene for type 1 and type 2 diabetes, modulates pancreatic beta cell apoptosis via regulation of a splice variant of the BH3-only protein Bim. PLoS Genet 9:e1003532

31. Marselli L, Thorne J, Ahn YB et al (2008) Gene expression of purified beta-cell tissue obtained from human pancreas with laser capture microdissection. J Clin Endocrinol Metab 93:1046-1053

32. Piaggi S, Novelli M, Martino L et al (2007) Cell death and impairment of glucose-stimulated insulin secretion induced by $2,3,7,8$ tetrachlorodibenzo- $p$-dioxin (TCDD) in the beta-cell line INS-1E. Toxicol Appl Pharmacol 220:333-340

33. Ehses JA, Perren A, Eppler E et al (2007) Increased number of isletassociated macrophages in type 2 diabetes. Diabetes 56:2356-2370

34. Richardson SJ, Willcox A, Bone AJ, Foulis AK, Morgan NG (2009) Islet-associated macrophages in type 2 diabetes. Diabetologia 52:1686-1688

35. In't Veld P, De Munck N, Van Belle K et al (2010) Beta-cell replication is increased in donor organs from young patients after prolonged life support. Diabetes 59:1702-1708

36. Gutierrez DA, Fu W, Schonefeldt S et al (2014) Type 1 diabetes in NOD mice unaffected by mast cell deficiency. Diabetes 63:38273834

37. Dotta F, Censini S, van Halteren AG et al (2007) Coxsackie B4 virus infection of beta cells and natural killer cell insulitis in recentonset type 1 diabetic patients. Proc Natl Acad Sci U S A 104:51155120

38. Collington SJ, Williams TJ, Weller CL (2011) Mechanisms underlying the localisation of mast cells in tissues. Trends Immunol 32: 478-485

39. Ylipaasto P, Kutlu B, Rasilainen S et al (2005) Global profiling of coxsackievirus- and cytokine-induced gene expression in human pancreatic islets. Diabetologia 48:1510-1522

40. Cardozo AK, Proost P, Gysemans C, Chen MC, Mathieu C, Eizirik DL (2003) IL- $1 \beta$ and IFN- $\gamma$ induce the expression of diverse chemokines and IL-15 in human and rat pancreatic islet cells, and in islets from pre-diabetic NOD mice. Diabetologia 46:255-266

41. Eizirik DL, Sammeth M, Bouckenooghe T et al (2012) The human pancreatic islet transcriptome: expression of candidate genes for type 1 diabetes and the impact of pro-inflammatory cytokines. PLoS Genet 8:e1002552

42. Campbell-Thompson M, Wasserfall C, Montgomery EL, Atkinson MA, Kaddis JS (2012) Pancreas organ weight in individuals with disease-associated autoantibodies at risk for type 1 diabetes. JAMA 308:2337-2339

43. Rodriguez-Calvo T, Ekwall O, Amirian N, Zapardiel-Gonzalo J, von Herrath MG (2014) Increased immune cell infiltration of the exocrine pancreas: a possible contribution to the pathogenesis of type 1 diabetes. Diabetes 63:3880-3890

44. Atkinson MA (2014) Losing a grip on the notion of $\beta$-cell specificity for immune responses in type 1 diabetes: can we handle the truth? Diabetes 63:3572-3574

45. Orinska Z, Bulanova E, Budagian V, Metz M, Maurer M, BulfonePaus S (2005) TLR3-induced activation of mast cells modulates $\mathrm{CD}^{+}$T cell recruitment. Blood 106:978-987

46. Nakamura T, Yoshikawa T, Noguchi N et al (2014) The expression and function of histamine $\mathrm{H}_{3}$ receptors in pancreatic beta cells. Br J Pharmacol 171:171-185

47. Martin S, Kolb-Bachofen V, Kiesel U, Kolb H (1989) Pathogenesis of low dose streptozotocin induced diabetes in mice: requirement for $\alpha 1$-adrenoceptor activation and vasoactive amine release. Diabetologia 32:140-142 